\title{
Morphotaxonomy of endophytic fungi on Cissus quadrangularis from Amravati (MS) India
}

\begin{abstract}
Endophytes play significant role to establish fungal diversity. The research interest has been increasing in ecology, biology and applications of endophytic fungi. It is believed that endophytic fungi are diverse in those areas where diversity of plants are diverse and certainly Melghat Forest is one among these areas which has huge plant diversity but studies on endophytic fungal diversity from this region extremely inadequate. In the present study widely used medicinal plant Cissus quadrangularis was investigated to isolate the endophytic fungi. Total eight endophytes were observed from different parts (stem, leaf and petiole) of the host by using standard methods. For the specific identification of species; morphological charchacters and dimensions of various fruiting bodies were studied microscopically.
\end{abstract}

Volume 5 Issue 2 - 2017

\section{Suradkar KP, Hande DV}

Department of Botany, Sant Gadge Baba Amravati University Amravati, India

Correspondence: Hande DV, Department of Botany, Sant Gadge Baba Amravati University Amravati, Shri Shivaji Science College, Shivaji Nagar, Amravati 444603(MS) India,Tel 917212660855, Fax 917212665485, Email dvhande@gmail.com

Received: June 05, 2017 | Published: July 24, 2017

Keywords: taxonomy, fungal endophytes

\section{Introduction}

The word 'endophyte' means "inside the plant" (endon Gr.=within, phyton=plant) and term was coined by De Bary in 1866 to define all microbes (including fungi, bacteria, cyanobacteria and actinomycetes) that reside within plant tissue.

The association between fungal endophytes and host plants may be symbiotic or antagonistic or slightly pathogenic in nature. ${ }^{1}$ Major impact of endophytes is observed on ecology, distribution and physiology along with immunity of plants. Almost all the plant species $(\sim 400,000)$ harbour one or more endophytic organisms. ${ }^{2}$ To date, only a few plants have been extensively investigated for their endophytic biodiversity and their potential to produce bioactive secondary metabolites. It is, therefore, important to determine endophytic biodiversity of medicinal plants. Identification, taxonomic position and mapping of fungi are challenging tasks. Out of many fungi about 70,000 fungal species had been isolated, identified and characterized. ${ }^{3,4}$ Manoharachary et al., 5 are of the opinion that about 27,000 fungal species have been described in India. Scientific community is continuously striving to search into the diversity of fungi and their natural potentials. The multiplicity of endophytic fungi and their role in various biochemical processes occupy most important place in the biological world and India has been the cradle for such fungi.

During mycological investigation of Melghat Forest of Amravati District several author collected and reported many rare and interesting fungal forms they are new to Maharashtra. ${ }^{6-12}$ The traditional taxonomy of fungi is based on morphological features like shape, size and colour of various fruiting bodies. ${ }^{13}$ In the present study isolated fungal species were also identified morphotaxonomicaly by studying their macroscopic and microscopic characteristics.

\section{Materials and methods}

\section{Collection of plant samples}

The plant samples were collected from Melghat forest of Amravati district. The samples were collected in sterilized polythene bags. The collected samples were brought to the laboratory and processed within $24 \mathrm{hrs}$ of collection.

\section{Isolation of the endophytic fungi}

Surface sterilization were done according to the method described by Suryanrayanan ${ }^{14}$ (Table 1) to remove the epiphytes. The surface sterilized explants then inoculated at $26 \pm 2^{\circ} \mathrm{C}$ into the Petri dishes containing potato dextrose agar (PDA). The plates were periodically observed for fungal growth.

Table I Surface sterilization of explants

\begin{tabular}{lll}
\hline Chemicals & Concentration & Time \\
\hline Ethanol & $70 \%$ & Imin \\
SDW & - & $3 \mathrm{~min} \times 4$ times \\
$\mathrm{NaOCl}$ & $4 \%$ & $30 \mathrm{sec}$ \\
$\mathrm{SDW}$ & - & $3 \mathrm{~min} \times 4$ times \\
Ethanol & $70 \%$ & $30 \mathrm{sec}$ \\
SDW & - & $3 \mathrm{~min} \times 4$ times \\
\hline
\end{tabular}

SDW, sterile distilled water; $\mathrm{NaOCl}$, sodium hypochlorite

\section{Microscopic observation}

Permanent slides were prepared from pure colonies of isolated endophytic fungi. Morphological characters such as pycnidia, conidia and condiogenous cells (Coelomycetes); conidia and conidiophores (Hyphomycetes) were studied under Carl Zeiss, Trinocular Research Microscope (Axioscope-A-1) with magnification of 5x, 10x, 40x and 100x.

\section{Mountants and stain}

In the present study microscopic observation of isolated endophytic fungi was initially done in water mountant. However, various fruiting structures were observed by mounting in lactophenol-cotton blue. This stain-cum-mounting medium has been used for different taxonomic groups of fungi. ${ }^{15,16}$ 


\section{Identification of endophytic fungi}

All the endophytic isolates were identified morphologically and placed in appropriate genera and species of fungi using standard taxonomic keys and monographs ${ }^{17-21}$ were referred for identification of endophytes.

\section{Observations and results}

\section{Arthrinium hydei Crous and Groenewald (Plate I, Figure I)}

Mycelium smooth, hyaline to pale brown, branched, septate, $2-3 \mu \mathrm{m}$ diameter. Conidiophores pale brown smooth, cylindrical, septate, branched, $22-34 \times 3-5 \mu \mathrm{m}$. Conidiogenous cell aggregated in clusters on hyphae, smooth, hyaline, doliiform. Conidia unicelled, brown, globose to lenticular with pale equatorial slit $10-22 \mu \mathrm{m}$ diameter in side view.

Remark: The species under study matched with $A$. hydei, and new to this region. A. hydei was isolated and cultured on PDA. Colonies developed were olive white with patches of grey to black.

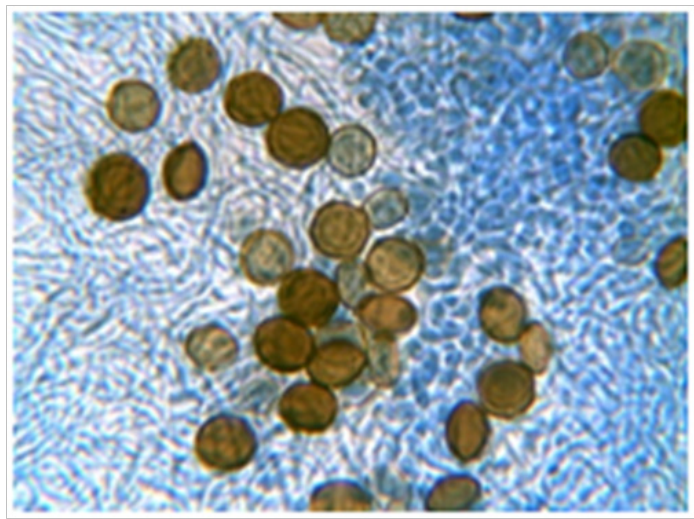

Figure I Mycelium with conidia of A. hydei.

Table 2 Comparison between species of Arthrnium

\begin{tabular}{llll}
\hline Species & Colony character(color) & Conidiophores & Conidia \\
\hline A. caricicola Kunze ex Fries & Black, pulvinate & $150 \mu \mathrm{m} \times 4 \mu \mathrm{m}$ & $36-54 \mu \mathrm{m} \times 9-12 \mu \mathrm{m}$ \\
A. hydei Crous & Olive white with patches of grey to black & $21.65-33.22 \mu \mathrm{m} \times 3.2-4.8 \mu \mathrm{m}$ & $10-22 \mu \mathrm{m}$ \\
A. marii Larrondo and Calvo & Whitish- black to olivaceous grey & $6-10 \times 2.5 \times 4 \mu \mathrm{m}$ & $7-10 \mu \mathrm{m}$ \\
A. phaeospermum (Corda) Ellis & Dark brown to greenish in color & $4.7-11.6 \mu \mathrm{m} \times 2.8-5.1 \mu \mathrm{m}$ & $10-16 \mu \mathrm{m} \times 3.9-7.2 \mu \mathrm{m}$ \\
\hline
\end{tabular}

Dense mycelial growth on PDA, colonies with uniform edges, color ranges from dark purple red to green brown in PDA. Sporodochia develop after approximately after 20days on PDA. Sporodochia powdery, brownish to grey black in color. Mycelium hyaline, smooth, septate, brown on maturation. Short conidiophores originated on hyphae in clusters. These conidiophores branched repeatedly and are visible as dense masses. Conidiophore hyaline, claviform, 1-3 septate, smooth up to $9-11 \mu \mathrm{m}$, producing a single dark gangliospore

\section{Arthrinium phaeospermum (Corda) Ellis (Plate I, Figure 2)}

Colonies dark brown to greenish, round, oval or irregular in shape. Mycelium hyaline to pale brown, smooth hyphae, $3-4 \mu \mathrm{m}$ in diameter. Conidiophores are cylindrical, narrow, erect or flexuous, straight, simple, smooth, hyaline $5-12 \times 3-5 \mu \mathrm{m}$ thick, dark brown with transverse septa $48-120 \mu \mathrm{m}$ long, $2-4.5 \mu \mathrm{m}$ in diameter between septa, basal cell somewhat flattened and round or irregular in shape. Conidia sessile or sometimes borne on short hyaline pegs along the sides of the conidiophores, which are somewhat flattened, lemon shape in surface view, triangular in side view but outer edge is curve and the corners round, brown pale at tips, smooth $10-16 \mu \mathrm{m}$ long, $4-7 \mu \mathrm{m}$ wide in surface view.

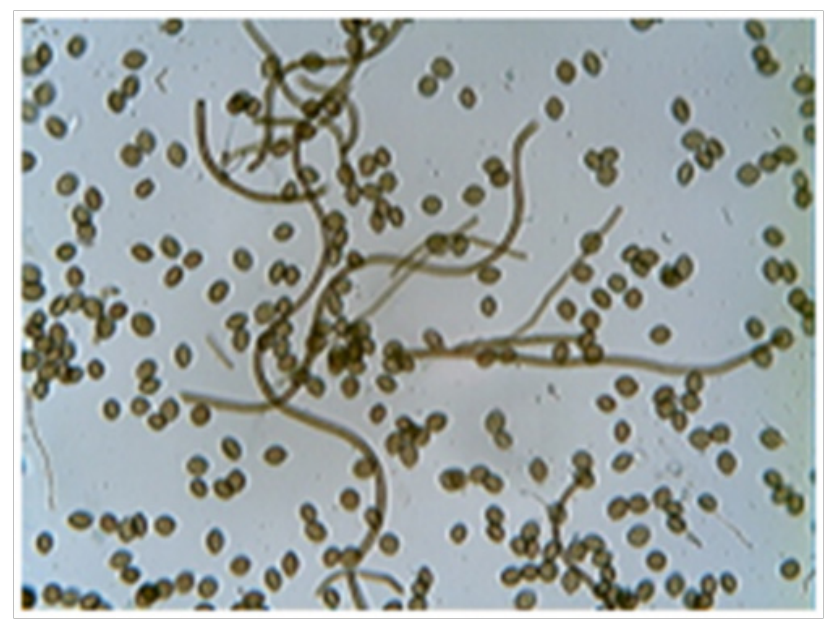

Figure 2 Mycelium with conidia of A. phaeospermum.

Remark: Isolated specie cultured on PDA. The colonies were dark brown to greenish in color, round, oval and irregular in shape (Table 2).

Table 3 Comparison between species of Epicoccum

\begin{tabular}{|c|c|c|c|}
\hline Species & Colony character (color) & Conidiophores & Conidia \\
\hline Epicoccum andropogonis (Ces) Schol- Schwarz & Greyish black sometime radish grey & $9 \times 12 \mu \mathrm{m}$ & $22-28 \mu \mathrm{m}$ \\
\hline Epicoccum nigrum Ehrenb.Ex.Schlecht. & Dark purple red to green brown & $8-11.5 \mu \mathrm{m}$ & 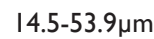 \\
\hline
\end{tabular}

Epicoccum nigrum Ehrenb.Ex.Schlecht. (Plate I, Figure 3)

terminally. Young conidia rounded, non septate and pale in color. Mature gangliospore golden brown or brown or olivaceous or black, 40 globosed or pyriform or sometimes of irregular angular shape, septate, muriform, verrucose, $15-54 \mu \mathrm{m}$ in diameter. Mature conidia contain multiple transverse and vertical septa.

Remark: The characters of the specimen understudy were allied with Epicoccum nigrum, hence assigned to the said species (Table 3). 


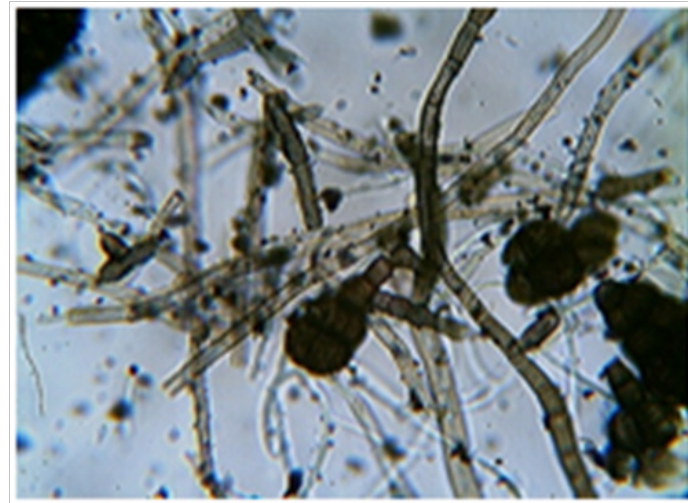

Figure 3 Mycelium with conidia of E. nigrum.

\section{Nigrospora oryzae (Berk \& Br.) Petch. (Plate I, Figure 4)}

Mycelium septate, branched, brown in colour. Conidiophore short, ampiliform, somewhat brown in colour, bearing single conidium at the tip. Conidia borne singly at the tip of the 113 conidiophores, globose or somewhat flattened, absolutely opaque black, with hyaline membrane on the upper side $24-28 \times 21-24 \mu \mathrm{m}$.

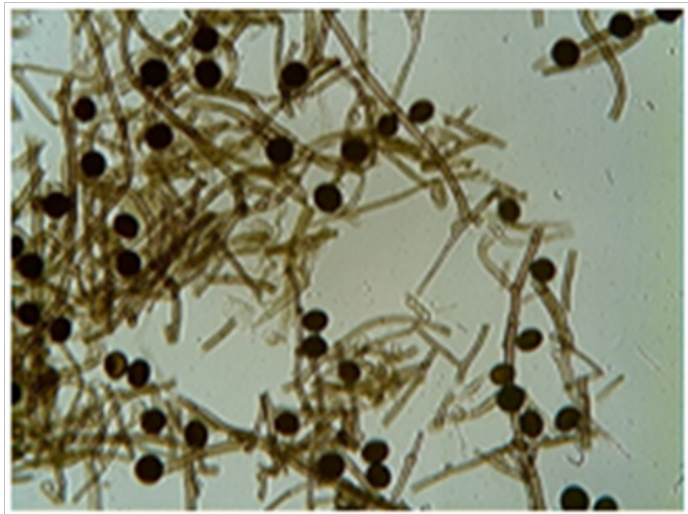

Figure 4 Mycelium with conidia of N. oryzae.

Remark: The species understudy found to be similar morphologically with Nigrospora oryzae (Table 4).

Table 4 Comparison between species of Nigrospora

\begin{tabular}{llll}
\hline Species & Colony character (color) & Conidiophores & Conidia \\
\hline Nigrospora oryzae (Berk \& Br) Petch. & Brown & Short, ampiliform \\
Nigrospora panici Zimm. & Yellowish & Short, slightly inflated \\
Nigrospora padwickii Prasad,Agnihotri and Agarwal & Pale brown & Short, swollen below apex $\quad 33.5-4 \mathrm{I} .8 \mu \mathrm{m} \times 3 \mathrm{I} .8-40.2 \mu \mathrm{m}$ \\
\hline
\end{tabular}

Nigrospora oryzae(Berk \& Br) Petch (Plate I, Figure 4)

\section{Pestalotiopsis funerea Stey. (Plate I, Figure 5)}

Pustules black, punctiform, globose-lenticular, 110-290 $\mu \mathrm{m}$ in dimeter. Conidia broad, tapering towards the base, clavate-fusoid, straight,5-celled, 15.5-28.5 $\times 6.6-9.2 \mu \mathrm{m}$, intermediate coloured cells guttalate, umber or olivaceous, equally coloured, lowest coloured cell sometimes slightly paler, slightly constricted at septa, apical appendages 1-2,4.8-6.5 $\mu \mathrm{m}$.

Remark: On comparison with known species, the present specie proved to be $P$. funerea (Table 5).

Table 5 Comparison between species of Pestalotiopsis

\begin{tabular}{llll}
\hline Species & Colony character(color) & Apical appendages & Conidia \\
\hline Pestalotiopsis funerea Stey. & Dark brown & 2-jan & $15.5-28.5 \times 6.6-9.2 \mu \mathrm{m}$ \\
Pestalotiopsis guepinii (Desm) Stey. & Olivaceous brown & 3-Jan & $12-15 \mu \mathrm{m} \times 5.5-6.6 \mu \mathrm{m}$ \\
Pestalotiopsis maculans (Corda) Nag Raj & Pale brown to moderate brown & 3-Feb & $10-15.5 \mu \mathrm{m}$
\end{tabular}

Pestalotiopsis funerea Stey (Plate I, Figure 5).

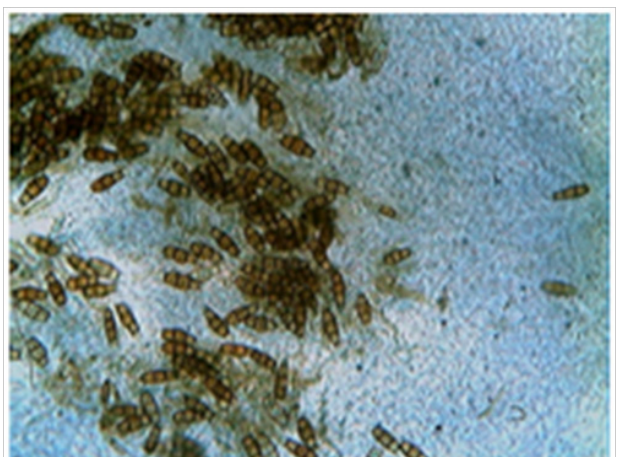

Figure 5 Mycelium with conidia of $P$. funereal.

\section{Pithomyces chartarum (Berk and Curtis) Ellis (Plate I, Figure 6)}

Colonies effused faint yellow, olive-green, shiny. Mycelium composed of a network of brown, mooth or rough walled hyphae. Conidiophores short peg like, $2-4 \mu \mathrm{m}$ wide, arising laterally on hyphae, subhyaline. Conidia produced singly as blunt out ends at the apex of conidiophores, oval, elliptical, obovoid, pale brown at young stage, dark brown at mature stage and often one or more oblique or longitudinal septa, $21-32 \mu$ mlong, $12-35 \mu \mathrm{m}$ wide, each conidium carrying away a part of conidiophores.

Remark: The specimen shows similar characters with Pithomyces chartarum, hence assigned to the said species (Table 6). 
Table 6 Comparison between species of Pithomyces

\begin{tabular}{|c|c|c|c|}
\hline Species & Colony character(color) & Conidiophores & Conidia \\
\hline Pithomyces chartarum (Berk and Curtis) Ellis & Olive-green & $1.8-3.9 \mu \mathrm{m}$ & $\begin{array}{l}20.6-31.8 \mu \mathrm{m} \times 11.7- \\
34.9 \mu \mathrm{m}\end{array}$ \\
\hline Pithomyces atro-olivaceous (Cooke \& Harkn) Ellis & Dark olivaceous brown & $\mathrm{I}-5 \mu \mathrm{m} \times \mathrm{I}-3 \mu \mathrm{m}$ & $15-35 \mu \mathrm{m} \times 7-10 \mu \mathrm{m}$ \\
\hline Pithomyces flavus Berk.\& Br. & At first yellow to olive green later dark olivaceous & $2-5 \mu \mathrm{m} \times 1.5-2 \mu \mathrm{m}$ & $28-45 \mu \mathrm{m} \times 15-26 \mu \mathrm{m}$ \\
\hline
\end{tabular}

Pithomyces chartarum(Berk and Curtis) Ellis (Plate I, Figure 6)

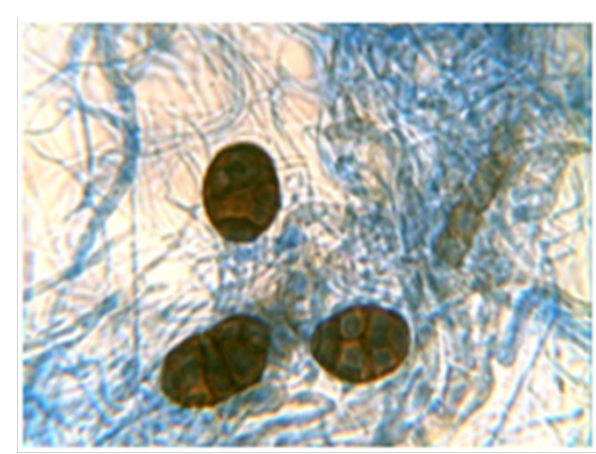

Figure 6 Mycelium with conidia of $P$. chartarum.

\section{Stachybotrys nilgirica Subram. (Plate I, Figure 7)}

Mycelium composed of creeping hyaline or pale colored, branched hyphae. Conidiophores (phialophores) scattered on substratum, erect, straight, hyaline, slightly narrow above, 2-3 septate (septa 21.28$39.9 \mu \mathrm{m}$ apart), swollen at base, $68.7-93.1 \mu \mathrm{m}$ long smooth, terminating in a cluster of about 6-7 phialides, apical cell of philophore $13.3-17 \mu \mathrm{m}$

Table 7 Comparison between species of Stachybotrys long and 2-6 $4 \mathrm{~m}$ wide and subhyaline. When young pale olive green, at maturity conidia borne singly acrogenously at the tip of phialides, 1-celled, globose, tuberculate, dark greenish black $15.3-27.8 \mu \mathrm{m}$ in diameter.

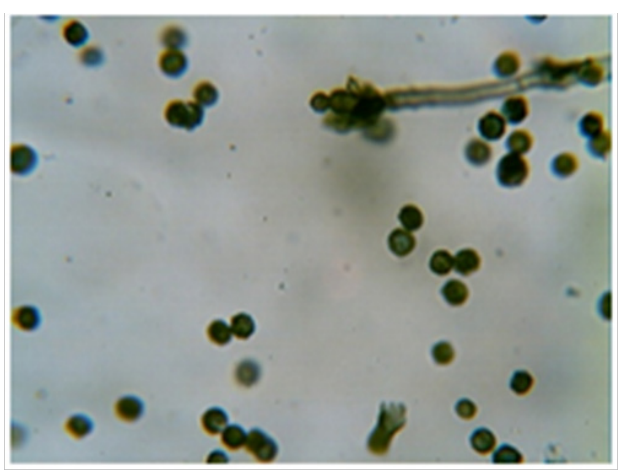

Figure 7 Mycelium with conidia of S. nilgirica.

Remark: The characters of the species understudy were allied with $S$. Nilgirica (Table 7).

\begin{tabular}{|c|c|c|c|c|}
\hline Species & Colony characters & Conidiophore & Phialides & Conidia \\
\hline S. chartarum (Ehrenb.) Hughes & $\begin{array}{l}\text { Colorless or whitish then } \\
\text { becoming black }\end{array}$ & $64-109 \mu \mathrm{m} \times 5 \mu \mathrm{m}$ & $\mathrm{II}-19 \mu \mathrm{m} \times 4.5-6.5 \mu \mathrm{m}$ & $15-16.5 \mu \mathrm{m} \times 3.2-7.3 \mu \mathrm{m}$ \\
\hline S. chlorohalonata Andersen and Thrane & Colonies thick dark black coloured & $73-91 \mu \mathrm{m} \times 13-16 \mu \mathrm{m}$ & $1 \mathrm{I}-16 \mu \mathrm{m} \times 4-6 \mu \mathrm{m}$ & $11-16 \mu \mathrm{m} \times 4-6 \mu \mathrm{m}$ \\
\hline S. nilgirica Subram. & Black & $68.7 \mu \mathrm{m}-93.1 \mu \mathrm{m}$ & $13.3-17 \mu \mathrm{m} \times 2-6 \mu \mathrm{m}$ & $15.3 \mu \mathrm{m}-27.9 \mu \mathrm{m}$ \\
\hline
\end{tabular}

Stachybotrys nilgiricaSubram (Plate I, Figure 7).

\section{Trimmatostroma hughesii Rao and Subhedar (Plate I, Figure 8)}

Colony olivaceous, brown, conidiophores macronematous, septate, sporogenous cell bears on top of conidiophores, 40-156 $\mu \mathrm{m}$ long and 4-7 $\mu \mathrm{m}$ wide. Conidiophores simple, sptate, hyaline. Conidia small, simple, catenulate, only one longitudinal septa over single transverse septa, $6-11 \mu \mathrm{m} \times 4-9 \mu \mathrm{m}$.

Remark: Characters of the present specimen match with Trimmatostroma hughesii, hence assigned to the same (Table 8).

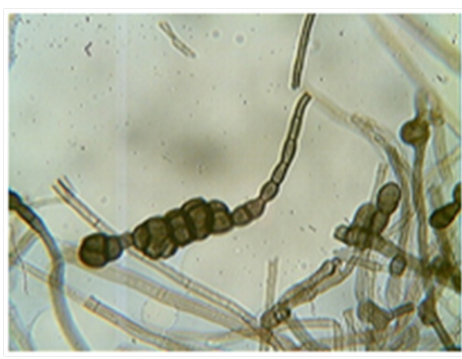

Figure 8 Mycelium with conidia of T. hughesii.

Table 8 Comparison between species of Trimmatostroma

\begin{tabular}{lll}
\hline Species & Colony character(color) & Conidiophores \\
\hline Trimmatostroma eriodictyonis (Dearn. and Barthol) Ellis & Dark brown & $45-68 \mu \mathrm{m}$ \\
Trimmatostroma hughesii Rao and Subhedar & Olivaceous, brown & $39.6-155.7 \mu \mathrm{m} \times 3.8-7.2 \mu \mathrm{m}$ \\
Trimmatostroma scutellare (Berk and Br.) Ellis & Pale brown to moderate brown & $30-50 \mu \mathrm{m}$ long, $2-4 \mu \mathrm{m}$ \\
\hline
\end{tabular}

Trimmatostroma hughesii Rao and Subhedar (Plate I, Figure 8) 


\section{Discussion}

Medicinal plants are reported as great reservoir of endophytes. ${ }^{22}$ One to several fungi could be isolated from single host..$^{23}$ In the present study total eight endophytic fungi were isolated from single host. Previous study proved that out of the total groups of fungi, anamorphic fungi are prevalent as endophytes in the plants screened throughout the world. ${ }^{24-26}$ The fungi found in the present investigation also showed dominance of anamorphic fungi.

Taxonomy is the discipline of classifications i.e. the assemblage of organisms into definite category (taxa). Morphological characters are very much useful in the field of taxonomy to give the special identity to the organism. In the fungal taxonomy morphological as well as microscopical characters play an important role to identify them. Colony morphology, type of hypha, spore and reproduction are characteristics which can used to identify the fungi.

Arthrinium genus observing similarities in all the two species studied and some specific differences in structure and colour etc of conidia, the investigator through same may assist in finding morphological differences. Conidiogenesis is particularly interesting. Conidiogenous cells tend to be dolliform to subcylindrical, pale brown with clear periclinal thickening. On further development these cells become ampulliform, with a prominent elongated neck. The neck can terminate in conidia either sympodially or in some species percurrently while in others with annelation etc. One must note that variation in conidiogenesis makes it difficult to compare these characters among taxa, as conidiophores can either be hyphae with lateral loci or be reduced to dolliform conidiogenous cells. Conidial ontogeny is holobastic. The apical holoblastic conidium, initially spherical, changes to lenticular. ${ }^{27}$ When conidium matures the neck of the conidiophores becomes narrower and a circular breaking can be seen on the outer wall conidiophores (this is initial of basauxic growth). This holoblastic nature and sizes of conidia vary as per species. The conidia of Arthrinium can develop a spontaneous break of the wall, thus, releasing protoplasmic contents.

Epicoccum nigrumis an anamorphic ascomycete distributed globally which colonizes on different types of soil and different host plants. Morpho-cultural characters make two groups of E. nigrum. The first group is showing yellow to orange mycelium while second group shows grey, pink, red or brown mycelium ${ }^{28,29}$ in her classic paper stated that large difference in pigmentation; spore-size and other morphological features, together with frequent sectorizations in culture plates indicate that E. nigrum has variable species

In present study Stachybotrys nilgirica wasidentified by comparing their characteristics with other species. The conidia of $S$. chartarum and $S$. chlorohalonata are ellipsoidal to oval while conidia of $S$ nilgirica are circular and small. The conidial wall of $S$. chartarum is smooth, while conidial wall in $S$. chlorohalonata is rough but wall of conidia of $S$. nilgirica is verrucose to tuberculate. ${ }^{30}$

Morphology of Trimmatostroma shows variation in size of conidia $T$. scutellare showed moderate brown to dark brown colony, mycelium subhyaline, conidiophore irregularly branched, septate, conidia obovate to subglobose, multicellular, dark brown. ${ }^{17,31}$ Trimmatostroma hughesii showed colony olivaceous, brown, conidiophores macronematous, septate, sporogenous cell bears on top of conidiophores, $40-156 \mu \mathrm{m}$ long and $4-7 \mu \mathrm{m}$ wide. Conidiophores simple, septate, hyaline. Conidia small, simple, catenulate, only one longitudinal septa over single transverse septa, $6-11 \mu \mathrm{m} \times 4-9 \mu \mathrm{m} .{ }^{32-34}$ The conidia of Trimmatostroma hughesii small, catenulate and only one longitudinal septa over single transverse septa is present while in Trimmatostroma scutellare having conidia large, with many cross and longitudinal septation.

\section{Conclusion}

The present investigation aims to study basic taxonomic study of endophytic fungi from Cissus quadrangularis from Melghat Forest of Amravati district of Maharashtra. Study concluded that several endophytes can associated with single host. The present findings reported first time from this region.

\section{Acknowledgements}

The authors are thankful to Principal, Shri Shivaji Science College, and Amravati for providing all necessary laboratory facilities.

\section{Conflict of interest}

The author declares no conflict of interest.

\section{References}

1. Arnold AE, Henk DA, Eells RA, et al. Diversity and phylogenetic affinities of foliar fungal endophytes in loblolly pine inferred by culturing and environmental pcr. Mycologia. 2007;99(2):185-206.

2. Tan RX, Zou WX. Endophytes: a rich source of functional metabolites. Nat Prod Rep. 2001;18(4):448-459.

3. Hawksworth DL. The fungal dimension of biodiversity: the 1.5 million species estimate revisited. Mycol Res. 1991;105:1422-142.

4. Hawksworth DL, Rossman A. Where are all the undescribed fungi? Phytopathology. 1997;87(9):888-891.

5. Manoharachary C, Sridhar K, Singh R, et al. () Fungal biodiversity: Distribution, conservation and prospecting of fungi from India. Current sci. 2005;89(1):58-71.

6. Dharkar NS, Hande DV, Subhedar AW. Some new species of Pleosporales from India. J Mycol Pl Pathol. 2006;36(1):28-30.

7. Hande DV. Dematiatious Hyphomycetes Fungi From Amravati MS Journal of Ecobiotechnology. 2012;4(2):172-174.

8. Subhedar AW, Hande DV, Dharkar NS, et al. Two new fungal species from Vidarbha India. J Mycol Pl Pathol. 2010;40(2):235-236.

9. Shahezad MA, Hande DV, Dharkar NS. Dinemasporium maximaumAppendage Bearing Coelomycete From Vidarbha (MS). J Mycol Pl Pathol. 2011;41(2):246-248.

10. Hande DV, Hiwarale SV. Diversity of Xylaria Species from Amravati Region, Amravati, MS, India. International Research Journal of Biological Sciences. 2013;2(1):67-69.

11. Hande DV, Kadu SR, Suradkar KP. Dictyoartrinium anmorphic fungi from Amravati region (MS) India. Int J of life Sciences. 2013;1(4):328329

12. Hande DV, Suradkar KP, Kadu SR. A Rare Myxomycetes Macbrideola from Amravati, Maharashtra. Int J of life Sciences. 2014;2(1):93-95.

13. Hawksworth DL, Sutton BC, Ainsworth GC. Ainsworth and Bisby's Dictionary of the Fungi. 7th ed. UK: Commonwealth Mycological Institute; $1983.445 \mathrm{p}$.

14. Suryanrayanan TS, Kumaresan V, Johnson JA. Fungal endophytes: The tropical dimension. In: Misra JK, Horn BW, editors. Trichomycetes and other fungal groups. USA: Science Publishers Inc Enfield NH; 2001. p. 197-207.

15. Hawksworth DL. Mycologists's handbook. UK: Commonwealth Mycological Institute publications; 1974 
16. Purvis MJRHS, Caller DC, Walls D. Laboratory Techniques in Botany. UK: Butterworth and Co Ltd; 1966.

17. Ellis MB. Dematiaceous hyphomycetes. UK: Commonwealth Mycological Institute; 1971. 608 p.

18. Rao VG, Subhedar AW. An undescribed species of Trimmatostrma Mycopathologia. 1976;58(2):79-870.

19. Sutton BC. The Coelomycetes, Fungi Imperfecti with pycnidia Acervuli and Stromata. UK: Robert Mac Lechose and Co Ltd, University of Glasgow; 1980. 696 p.

20. Subramanian CV. Hyphomycetes. India: Indian Council of Agricultural Research; 1971. p. 1-930.

21. Barnett HL, Hunter BB. Illustrated Genera of Imperfect Fungi. USA: Burgess Publishing Company; 1972. 240 p.

22. Strobel GA. Rainforest endophytes and bioactive products. Critical Review in Biotechnology. 2002;22(4):315-333.

23. Petrini O. Taxonomy of endophytic fungi of aerial plant tissues. In: Fokkema NJ, Van Den Heuvel J, editors. Microbiology of the Phyllosphere. UK: Cambridge University Press; 1986. p. 175-187.

24. Bussaban B, Lumyong S, Lumyong $P$, et al. Two new species of endophytes (ascomycetes) from Zingiberaceae. Nova Hedwigia. 2001;73:487-493.

25. Suryanarayanan TS, Murali TS, Venkatesan G. Ouccurance and distribution of fungal endophytes in tropical forests across a rain fall gradient. Can J Bot. 2002;80(8):818-826.
26. Gond SK, Verma VC, Kumar A, et al. Study of endophytic fungal community from different parts of Aeglemarmelos Correae (Rutaceae) from Varanasi (India). World J Microb Biotechnol. 2007;23(10):13711375.

27. Cole GT, Samson RA. Patterns of development in conidial fungi. UK: Pitman Press; 1979. 190 p.

28. Favaro LC, de Melo FL, Aguilar-Vildoso CI, et al. Polyphasic Analysis of Intraspecific Diversity in Epicoccumnigrum Warrants Reclassification into Separate Species. Plos One. 2011;6(8):e14828.

29. Schol-Schwarz MB. The genus Epicoccum. Trans Br Mycol Soc. 1959;42:149- 173 .

30. Morgan-Jones G, Sinclair RC. Notes on Hyphomycetes. Xxxiii. Stachybotrys sphaerospora sp.nov. from South Africa. Mycotaxon. 1980; $10: 372-374$.

31. Sutton BC, Ganapathi A. Trimmatostroma excentricum sp. nov., on Eucalyptus from New Zealand andFiji. New Zealand Journal of Botany. 1978;16(4):529-533.

32. Crous PW, Braun U, Hunter GC, et al. () Phylogenetic lineages in Pseudocercospora. Studies in Mycology. 2013;75(1):37-114.

33. De Bary A. Morphologie und Physiologie der Pilze, Flechten, und Myxomyceten. Germany: Hofmeister's Handbook of Physiological Botany; 1866:2.

34. Ellis MB. Dematiaceous Hyphomycetes. VI. Mycological Papers. $1965 ; 103: 1-46$. 